\title{
Pesan Dakwah tentang Nikah di Media Sosial Instagram
}

\author{
Nurasiah Ismail*, Zainal Abidin, dan Uwes Fatoni \\ Jurusan Komunikasi dan Penyiaran Islam, Fakultas Dakwah dan Komunikasi, \\ UIN Sunan Gunung Djati, Bandung \\ *Email: ismail.nurasiab80@gmail.com
}

\begin{abstract}
ABSTRAK
Tujuan penelitian ini untuk mengetahui makna pesan dakwah tentang nikah di media sosial instagram pada akun@nikahbarokah yang terumuskan di dalam pertanyaan bagaimana makna denotasi, makna konotasi dan mitos pesan dakwah tentang nikah dalam akun instagram @ nikahbarokah. Metode yang digunakan dalam penelitian ini adalah analisis semiotika yang berbentuk analisis data yaitu dengan menentukan quote, menafsirkan quote, menyangkutkan dengan yang dianggap masyarakat bernilai dengan makna semiotika berupa makna denotasi, makna konotasi, makna mitos yang dianggap mampu untuk mengenali tanda dan pesan yang tersembunyi dibalik quote pesan dakwah tentang nikah pada akun instagram @nikahbarokah. Hasil dari penelitian disimpulkan bahwa pesan dakwah tentang nikah yang diposting pengelola akun@nikahbarokah selama bulan Oktober sampai Desember 2016 terdapat 8 quote pesan dakwah diklasifikasikan berdasarkan tahap pernikahan yaitu taaruf, nikah dan pasca nikah dalam aspek fisiologis (sakinah), psikologis (mawadah), dan sosiologis (rahmab). Secara denotatif postingan yang terdapat pada gambar mengandung unsur gambar, tulisan kata-kata dan secara konotatif yang berkaitan dengan makna yang terdapat pada denotasi, dan secara makna mitos yang berkaitan dengan kehidupan sehari-hari.
\end{abstract}

Kata Kunci : pesan dakwah; nikah; media sosial; Instagram.

\section{ABSTRACT}

The purpose of this research is to know the meaning of message of da'wah about marriage in social media of instagram on account of @ nikabbarokab which is formulated in the question how the meaning of denotation, connotation, and myth of da'wah message about marriage in account instagram@niabbarokah? The method 
used in this study is semiotics analysis in the form of data analysis that is by determining quote, interpreting quote, menyangkutkan with what is considered a valuable society with the meaning of semiotics in the form of denotation meaning, connotation meaning, the meaning of myths are considered capable to recognize the signs and messages bidden behind quote message da'wah about marriage on account instagram@niabbarokah. The result concluded that the message of da'wah about marriage posted by account manager of @nikabbarokah during October to December 2016 there are 8 quote of message of da'wah classified based on the stage of marriage is ta'aruf, marriage and post marriage in physiological aspects (sakinab), psychological (mawadah), and sociological (rahmah). In denotative post contained in the picture contains elements of images, writing words and connotative with regard to the meaning contained in denotation, and the meaning of myths relating to daily life.

Keywords: message of da'wah; marriage; social media; instagram

\section{PENDAHULUAN}

Dakwah merupakan kegiatan rutinitas dalam keseharian karena dakwah adalah kewajiban yang harus dilakukan oleh seruruh umat muslim. Dakwah juga dapat dikatakan sebagai gejala sosial yang terjadi pada seseorang atau masyarakat mengenai perilaku yang tidak sesuai dengan ajaran Allah Swt. Dakwah dapat dipandang sebagai proses penyampaian pesan dari da'i kepada mad'u untuk selalu berada dijalan Allah, menjauhi larangan-Nya dan mengikuti perintah-Nya. Dalam melaksanakan dakwah tidak ada batas ruang dan waktu. Dalam proses penyampaianya tidak semua bisa berdiri didepan mimbar karena tidak semua mempunyai kemampuan tersebut. Proses dakwah dapat dilaksanakan melalui beberapa kegiatan dengan lisan atau tulisan (dakwah bi al-lisan dan bi alqalam) dan juga bisa dengan perilaku atau perbuatan (dakwah bil-hal).

Melihat perkembangan teknologi, televisi maupun radio juga bisa dijadikan sebagai media untuk berdakwah seperti Ustadzah Mamah Dedeh dalam acara Mamah \& Aa, dalam chanel Indosiar. Munculnya teknologi yang semakin maju, bermunculan juga media sosial dengan tokoh para da'i yang memanfaatkan media sosial sebagai media dakwah. Kehadiran media tersebut dapat dimanfaatkan ditengah masyarakat untuk menyampaikan pesan dakwah khususnya melalui internet. Perkembangan internet menjadikan kegiatan yang awalnya terasa sulit menjadi mudah. Melalui internet, internet sebagai jaringan komunikasi yang bisa menghubungkan seluruh orang didunia termasuk memudahkan para da'i untuk menyampaikan pesan dakwah seperti di media sosial sehingga 
semua masyarakat dapat mengetahui perkembangan Islam secara beragam dan menyeluruh. Media sosial ini banyak digunakan oleh generasi milenial, maka dengan berdakwah di media, khususnya media sosial menarik untuk para remaja. Media sosial tidak terlepas dari sisi negatif, banyak kejahatan yang dilakukan akibat penyalahgunaan media sosial, seperti penipuan, penculikan bahkan pembunuhan dan yang marak pobia, akan tetapi media sosial juga memiliki banyak sisi pesan positif jika diarahkan pada pesan pesan dakwah, terutama pesan pesan yang berkaitan dengan kebutuhan remaja yaitu tentang hubungan lawan jenis seperti pacaran, taaruf, nikah, dan berkeluarga. Media sosial, media yang digunakan untuk mempublikasikan konten seperti profil, aktivitas.

Instagram adalah salah satu media sosial yang sering digunakan dan memiliki fitur yang menarik, peranan Instagram dalam media sosial dalam mensyiarkan ajaran Islam dengan melalui unggahan-unggahan foto atau gambar quote, video, lalu disisipkan deskripsi pesan-pesan oleh pemilik akunnya. Beberapa diantara akun instagram yang memiliki motivasi untuk para remaja seperti@wanitashaleha akun ini berisi tentang motivasi untuk menjadi wanita shaleha, mengajak para wanita untuk belajar menjadi wanita solehah untuk suaminya dan orangtuanya, @istiqamahbersamamu, akun ini memberikan motivasi, quote pesan-pesan dakwah agar segera berhijrah dan juga memberikan pesan bahwa berhijrah itu mudah, tapi yang sulit itu istiqamahnya. Ada juga akun@nikahbarokah, akun ini berisi tentang pesan pesan dakwah tentang nikah. dakwah yang memotivasi tentang pesan pernikahan, menikah memuliakan sunah, seperti pesan perkenalan atau taaruf, pesan bersabar menenti jodoh, pesan bahwa menikah itu membukakan pintu rezeki, atupun untuk pasangan yang sudah menikah ataupun pasangan yang sudah menikah.

Akun@nikahbarokah ini mempunyai pengikut 373.000 dan 7.693 postingan pesan yang diunggah dalam akun@nikahbarokah ini banyak pesan dakwah yang memotivasi tentang pesan pernikahan, menikah memuliakan sunah, seperti pesan perkenalan atau taaruf, pesan bersabar menenti jodoh, pesan bahwa menikah itu membukakan pintu rezeki, atupun untuk pasangan yang sudah menikah ataupun pasangan yang sudah menikah.

Pesan yang akan diteliti dalam instagram ini adalah pesan-pesan tentang nikah yang berbentuk quote, dalam semiotika quote dibahas dalam tanda. Dalam semiotika Rolad Bartes menganalisis makna dari tanda, yaitu konotasi, denotasi dan mitos. Dalam konteks ini maka dilihat dari 
quote yang ada pada akun @nikahbarokah. Maka peneliti menganggap masalah ini menarik untuk diteliti, penulis tertarik untuk membahasnya dalam bentuk skripsi dengan judul Pesan Dakwah Tentang Nikah Di Media Sosial Instagram (Analisis Semiotika Pesan Dakwah pada Akun Instagram @nikahbarokah). Maka terumuskan dalam pertanyaan terumuskan di dalam pertanyaan bagaimana makna denotasi pesan dakwah tentang nikah dalam akun instagram @nikahbarokah, bagaimana makna konotasi pesan dakwah tentang nikah dalam akun instagram @nikahbarokah dan Bagaimana mitos pesan dakwah tentang nikah dalam akun instagram@nikahbarokah?.

\section{LANDASAN TEORITIS}

Pesan dakwah menurut bahasa maudlu' al-da'wah sesuatu yang disampaikan da'i kepada mad'u. Sedangkan menurut istilah ialah semua bahan atau sumber yang dipergunakan atau yang akan disampaikan oleh da'i kepada mad'u dalam kegiatan dakwah untuk menuju tercapainya kegiatan dakwah (Aziz, 2008:318). Dalam bahasa Arab dakwah berasal dari kata da'a, yad'u, da'watan bermakna seruan, panggilan, undangan atau do'a. Sedangkan menurut Tasmara (1997: 43) pesan dakwah bersumber dari Al-Qur'an dan Sunnah yang diyakini sebagi pedoman bagi setiap tindak kehidupan orang muslim. Dari kedua pendapat di atas maka pesan dakwah adalah pesan yang dimaksudkan agar manusia mau menerima dan memahami serta mengikuti ajaran agama Islam sehingga benar-benar diketahui, dipahami, dihayati dan selanjutnya diamalkan sebagai pedoman kehidupan.

Sumber pesan dakwah menurut Abu Zahrah (1994: 75-77) bersumber dari Al-Quran, As-Sunnah dan riwayat hidup Rasulullah. Pada dasarnya Al-Quran adalah dakwah yang paling kuat untuk pengembangan Islam dalam Al-Quran mencakup semua cerita orang-orang yang terdahulu serta hukum-hukumnya. Sejarah hidup Rasulullah juga bagian yang terpenting bagi kaum muslimin untuk berdakwah. Adapun didalamnya terdapat beberapa kalasifikasi ayat tentang kehidupan dapat dikategorikan untuk penyampaian pesan dakwah.

Kategorisasi pesan dakwah menurut Samsul Munir Amin (2009: 89) mencakup kultur Islam yang murni yang bersumber dari kedua sumber tersebut dengan memperhatikan situasi dan kondisi masyarakat. Secara umum materi pesan dakwah yang bersumber dari ajaran Islam dibagi menjadi tiga macam. Keimanan (Aqidah) kepercayaan kepada Allah SWT, 
Tentang tauhid. Keislaman (Syariat), hukum, peraturan sistem keislaman yang disyari'atkan oleh Allah SWT untuk umat manusia. Budi Pekerti (Akhlak) atau moral merupakan pendidikan jiwa agar jiwa seseorang dapat bersih dari sifat-sifat yang tercela dihiasi dengan sifat terpuji. Menyeru atau mengajak merupakan inti dalam proses (Hikam: 259).

Tujuan dakwah yang dikemukan oleh Afandi (1984: 3) yaitu perubahan dalam diri manusia, baik pribadi, maupun keluarga, masyarakat, atau cara berpikirnya berubah atau cara hidupnya berubah menjadi lebih baik. Tujuan dakwah pada intinya bertujuan mengingatkan umat muslim untuk berbuat amar ma'ruf dan menjauhi nahyi munkar.

Pengertian pernikahan menjadi sebabnya sah sebuah ikatan suami istri dan halal bagi keduanya untuk melakukan hubungan badan. Seperti halnya menurut Sudarsono (1991: 62) nikah mempunyai arti mempertemukan, menyatukan atau menjodohkan. Nikah juga bisa berarti, al-jam'u dan al-dhamu dalam arti menyatu atau terkumpul, (Sohari, Tihami. 20013: 7).

Sebelum proses pernikahan ada perkenalan yang disebu dengan ta'aruf dalam bukunya Chudlori (2012: 48) adalah nadzru proses ini biasanya melihat calon. Seorang lelaki atau pun perempuan diwajibkan untuk melihat wajah calon tersebut. Boleh memandang pada bagian wajah dan sepasang telapak tangan saja, karena hal itulah yang dibutuhkan (Syuaisyi'. 2003: 27). Hal ini berkaitan untuk melancarkan tahapan kbitbah.

Kitabah dalam bahasa Indonesia meminang berasal dari kata pinang yang dimaknai thalabah al mar'ah li al-zawaj. Secara istilah kitbah adalah permintaan yang dinyatakan dari pihak laki-laki untuk menikahi seorang (Dahlan, 2015: 10). Ketika proses kbitbah dimulai, di Sunnah kan untuk melakukan khutbah terlebih dahulu. Kegiatan khutbah tersebut untuk menasihati antara kedua belah pihak. Setelah itu peminangan (ji'tukum fi karimatikum) saya mendatangi kalian untuk melamar wanita mulia kalian. Apabila diwakilkan maka wakilnya yang berkata (ji'tukum anhu khotiban kharimatakum) saya mendatangi kalian sebagai ganti dari orang yang mewakilkan kepadaku untuk melamar wanita mulia kalian (Chudlori, 2012: 55).

Istilah sakinah berasal dari kata sakana yang berarti tenang setelah sebelumnya bergejolak. Pernikahan memberikan ketengan pada suami istri karena setelah menikah libido menjadi tenang dan tersalurkan sebab sebelumnya menuntut pemuasan (Al-Farisi, 2008: 40).

Mawadah atau cinta terhadap lawan. Mawaddah menurut Ibnu 
Abbas adalah cinta seseorang terhadap pasangannya sedangkan menurut pendapat yang lain mawaddah adalah jimak, Allah memberikan naluri libido kepada manusia sebab itulah seseorang saling jatuh cinta yang disebut dengan mawaddah. (Al-Farisi, 2008: 41)

Rabmah Cinta kasih atau kasih sayang, cinta yang berlandaskan kasih, bukan cinta yang berdasarkan libido. Mawaddah dan rahmah seperti ikatan atau perekat dalam rumah tangga yang akan membuat suami istri terus bersatu. (Al-Farisi, 2008: 54-55)

Media Sosial Instagram media komunikasi yang efektif dalam bersosialisasi dengan masyarakat, sebagai bentuk kreatifitas para ahli tekhnologi yang hadir ditengah masyarakat (Kamil, 2014: 357). Dewasa ini media sosial sangat digemari oleh banyak orang terutama generasi milenial didalamnya terdapat media sosial dan mempunyai karakter berbeda. Karakter Informasi, Karakter Arsip. Karakter Interaksi, Dari beberapa macam karakter media sosial salah satu karakter interaksi tepat dijadikan sebagai interaksi untuk berdakwah di media sosial. Media Sosial Instagram Sebagai Media Dakwah dapat digunakan oleh siapapun, sebagai sarana untuk berbagi foto dan video sebagai media untuk berdakwah

Pengertian Instagram singkatan dari "instant-telegram" artinya mengirimkan berita secara langsung (@mrbambang, 2014: 8). Disusun dari dua kata, "Insta" dan "Gram". Arti dari kata pertama diambil dari istilah "Instan" atau serba cepat/mudah. Sedangkan kata "Gram" diambil dari "Telegram" yang maknanya dikaitkan sebagai media pengirim informasi yang sangat cepat. Sebuah aplikasi berbagi foto yang memungkinkan pengguna mengambil foto, menerapkan filter digital, dan membagikannya ke berbagai layanan jejaring sosial. Satu fitur yang unik di Instagram adalah memotong foto menjadi bentuk persegi, sehingga terlihat seperti hasil DSLR

Komponen dalam Instagram logo gambar kamera yang didesain semenarik mungkin, hanya fokus untuk memposting foto dan video. Dalam Instagram terdapat beberapa komponen (@mrbambang, 2012: 28) yaitu halaman, pencarian, share, dan efek foto. Intreraksi media sosial Follow (pengikut), like (suka) tanda love, Comment (komentar), caption foto dapat ditambahkan juga lokasi foto serta menandai oarng yang ada dalam foto tersebut. Dari foto-foto dan lambang terdapat simbol atau tanda, dalam pengembangan ilmu sekarang maka foto atau quote dapat dianalisis melalui teori semiotika yaitu teori yang membahas tentang tanda. Aliran semiotika Roland Barthes yang menyebutkan semiotika konotasi 
Nurasiah Ismail, Zainal Abidin, dan Uwes Fatoni

denotasi, dan mitos.

Semiotika Roland Barthes salah satu pengusung teori semiotika yang mengikuti pemikiran dari Saussure. Lebih dalamnya Barthes membahas sistem pemaknaan dua tahap signifikasi Kunci dari semiotika Barthes yaitu makna denotasi, makna konotasi dan makna mitos (Sobur, 2012: 128).

Dari kesimpulan Barthes (Sobur, 2012: 128) terdapat tiga tahap cara menganalisis yaitu pertama, signifikasi tahap denotasi, makna paling nyata dari tanda adalah hubungan antara penanda (signifier) dan petanda (signified). Kedua, signifikasi tahap konotasi menggambarkankan interaksi yang terjadi ketika tanda bertemu dengan perasaan atau emosi pembaca. Ketiga, signifikasi tahap mitos atau mitologi, bagaimana kebudayaan menjelaskan atau memahami beberapa aspek tentang realitas atau gejala alam. Ketiga analisi di atas akan diterapkan pada penelitian, yang berjudul pesan dakwah tentang nikah pada media sosial instagram.

\section{HASIL DAN PEMBAHASAN}

Profil Halaman awal pada akun media sosial instagram@nikabbarokah memberikan info tentang akun@nikabbarokab yang memanafaatkan halaman awal akun dengan identitas akun@nikabbarokab dengan profil, tagline, kontak, informasi akun fanspage, alamat pemilik akun, postingan, follower dan following

Sejarah Akun@nikahbarokah adalah salah satu nama akun di media sosial instagram yang dibuat dan didaftarkan oleh Ghisti Gandari. Latar belakang akun ini muncul, berangkat dari latar belakang pemilik akun itu sediri yang pernah berpacaran dan pada akhirnya menyadari bahwa pacaran sebelum menikah hanya akan membuang buang waktu saja dan membawa kepada kemadharatan, sehingga termotivasi membuat akun (a)nikahbarokah untuk menyemangati para remaja agar tidak terjerumus pada pacaran yang penuh dengan mendekati kemaksiatan (Wawancara. Gandari. 05 Agustus 2017). Setiap harinya memposting materi berupa foto, video, yang didapat dari foto yang di tag ke akun@nikahbarokah ataupun dengan mencari materi yang difokuskan pada hijrah, memantaskan diri, ta'aruf, pernikahan, dan rumah tangga pembekalan ilmu sebelum menikah dan setelah menikah untuk membentuk keluarga yang sakinah, mawaddah, rohmah dan penuh berkah.

Visi dan misi pemilik akun@nikahbarokah adalah menyampaikan pesan dakwah dengan mendukung para sahabat yang berkeinginan untuk 
berhijrah menuju lebih baik, agar yang masih pacaran termotivasi segera menikah meninggalkan dosa dalam berpacaran, semakin banyak pasangan menjalani pernikahannya dengan kehidupan yang sakinah, mawaddah dan rahmah (wawancara, Gandari. 09 Agustus 2017).

Analisis quote pesan dakwah tentang nikah dalam akun instagram (a)nikahbarokah diklasifikasikan menggunakan pendekatan analisis semiotika Roland Barthes dengan signifikasi makna denotasi, konotasi, dan makna yang di unggah pada media sosial instagram akun (anikahbarokah postingan bulan september hingga desember 2016.Quote pesan dakwah berkaitan dengan nikah, proses ta'aruf, nikah dan pasca nikah. Berdasarkan analisis penulis mengumpulkan 8 data yang diperoleh bersangkutan dengan ta'aruf, nikah, dan pasca nikah tentang sakinah, mawaddah, dan Rahmah. Didapatkan 1 quote yang berkaitan dengan ta'aruf, 2 quote tentang nikah, dan 5 pasca nikah yaitu 2 quote tentang sakinah, 2 quote pesan tentang mawadda, dan 1 quote pesan tentang rabmah yang akan dibahas dibawah.

\section{Taaruf}

Postingan pesan dakwah dalam instagram akun@nikahbarokah terkait tentang ta'aruf yang di unggah pada 23 desember 2016.

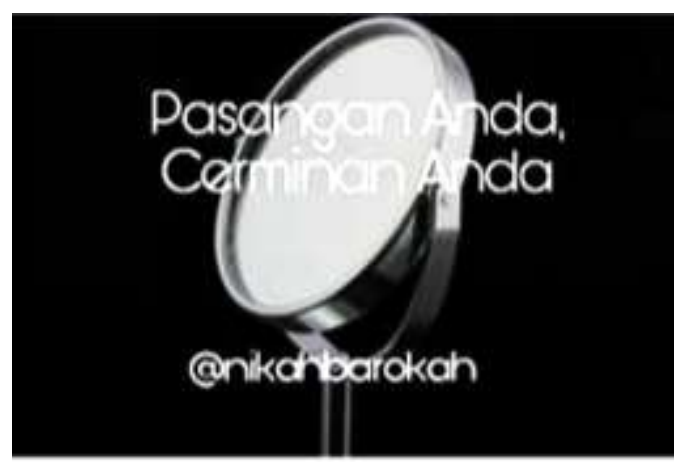

Gambar 1 Quote Taaruf

Makna Denotasi dari Gambar 1 memiliki objek yang pertama terdapat sebuah gambar kotak dengan backgraund hitam dan foto sebuah cermin berdiri berwarna silver yang berbentuk bulat sebagai latarnya. Objek yang kedua tulisan berwarna putih dengan font century gothic dan size font berukuran kurang lebih 20 dengan tulisan "Pasangan Anda, 
Nurasiah Ismail, Zainal Abidin, dan Uwes Fatoni

Cerminan Anda" dan di bawahnya terdapat tulisan@nikahbarokah yang di unggah oleh pemilik akun@nikahbarokah.

Makna konotasi diambil dari gambar 1. Pertama gambar kotak dengan backgraund hitam bila dikaitkan dengan ta'aruf adalah sebuah misteri dalam proses mendapatkan pasangan yang masih belum di ketahui. Warna hitam sendiri dapat di artikan sebagai pelindung, misteri ataupun elegan. Warna putih diartikan penghormatan, masa muda, kebenaran, penyerahan, kehidupan, perkawinan (Widjaja, 2016: 17). Ta'aruf dalam Islam adalah proses yang elegan dalam melangkah ke sebuah pernikahan yang masih menjadi misteri sebelum adanya kesepakan dari kedua belah pihak.

Makna tulisan putih quote di atas "Pasangan Anda, Cerminan Anda" pada quote di atas jika dikaitkan dengan ta'aruf adalah sebuah proses untuk saling mengenal tidak dengan pacaran yang mendekati perbuatan tidak diinginkan untuk menuju kehidupan rumah tangga dengan berpasrah pada Allah untuk mendapatkan yang terbaik.

Cermin adalah kaca untuk melihat pantulan diri kita. Menurut Daryanto (2014: 59) apabila kita memandang ke dalam cermin dan kita tidak melihat diri kita, tetapi melihat diri kita yang dipantulkan oleh cermin yang sedang memandang kita. Jika dikaitkan dengan tulisan quote di atas "Pasangan Anda, Cerminan Anda" cermin merupakan pantulan yang ada pada diri kita begitupun pasangan hidup, tak akan jauh dari sikap dan sifat yang ada pada diri sendiri jika ingin mendapatkan pasangan hidup yang baik maka berkacalah padadiri kita apakah sudah baik atau masih harus di perbaiki, jika masih belum baik maka mulailah dari sekarang memperbaiki diri untuk mendapatkan pasangan yang baik.. Tulisan font century gothic adalah jenis tulisan san serif yang memiliki makna kurang formal namun mengandung arti kesan karakter yang kuat dan bersahabat (Zainal \& Abidin, 2014: 13). Jenis tulisan ini juga mempunyai karakter streamline artinya mempersingkat jika dikaitkan dalam ta'aruf maka mempersingkat perkenalan menuju proses pernikahan. Tulisan @ nikahbarokah yang ditulis paling bawah menanadakan bahwa tulisan quote pesan dakwah pada gambar 3.2 dibuat oleh pemilik akun@nikahbarokah dan diposting oleh pemilik akun.

Makna mitos pada gambar 1 foto cermin dengan tulisan quote di atas memiliki kaitan dengan budaya dalam konteks ta'aruf. Cermin dikenal oleh masyarakat sebagai alat untuk berkaca melihat diri. Quote pesan dakwah di atas berkaitan dengan pasangan hidup, sudah menjadi hukum 
alam bahwa setiap orang ingin mendapatkan pasangan hidup yang terbaik. Maka untuk mendapatkan pasangan yang baik tentunya harus dengan proses yang baik pula, ta'aruf adalah salah satu jalan terbaik untuk mendapatkan calon pasangan hidup. Pesan dakwah yang disampaikan bahwa jodoh anda cerminan anda, pengibaratan yang sudah biasa terdengar ditelinga. Menurut Faqih (2006: 64) dalam surat An-Nur ayat 26:

"Perempuan-perempuan yang keji untuk laki-laki yang keji, dan laki-laki yang keji untuk perempuan yang keji( pula), sedangkan perempuan-perempuan yang baik untuk laki-laki yang baik dan lakilaki yang baik untuk perempuan-perempuan yang baik (pula).mereka itu bersih dari apa yang dituduhkan orang. Mereka memperoleh ampunan dan rezeki yang mulia."

Ayat ini menjelaskan bahwa mungkin sebuah ketentuan agama, perkawinan orang baik dengan orang jahat adalah haram. Hal ini seperti isi ayat ketiga dalam surah ini yang mengatakan: pelaku zina laki-laki tidak boleh kawin kecuali dengan pezina perempuan...mungkin yang dimaksud dalam ayat ini adalah pasangan-pasangan hidup yang cocok secara intelektual, keyakinan, dan akhlak. Allah tidak menjajikan bahwa yang berpeci berpasangan dengan yang bercadar akan tetapi Allah menjanjikan bahwa yang baik untuk yang baik pula. Pasangan itu dalam masyarakat dianggap sebagai cerminan sehingga dalam gambar tersebut digunakanlah foto cermin.

\section{Nikah}

Pemilik akun@nikahbarokah memposting pesan dakwah yang berkaitan tentang nikah.

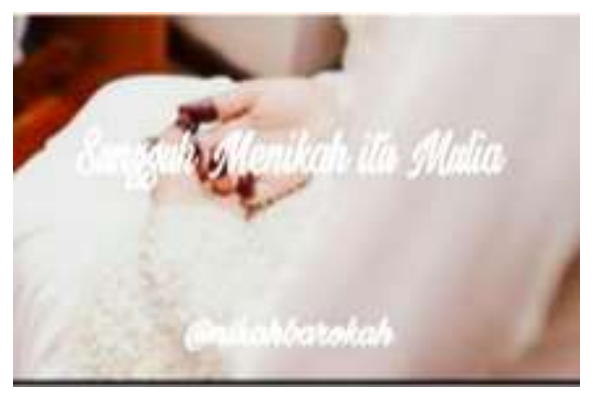

Quote Quote Nikah itu Mulia 
Makna Denotasi, pada gambar 3.3 di atas terdapat dua objek. Objek yang pertama background seorang perempuan memakai gaun putih dan tangan memakai hena yang berwarna merah dengan posisi tangan seperti sedang berdo'a.Objek kedua tulisan "Sungguh Menikah itu Mulia" dengan ukuran font kurang lebih 20 dengan font freehand521 B dan di bawahnya terdapat tulisan@nikahbarokah yang diposting oleh pemilik akun.

Makna Konotasi, terkait pada gambar 3.3 quote di atas terdapat foto pengantin perempuan yang memakai gaun putih dan memakai hena dengan warna merah. Warna putih mempunyai arti suci, dan warna merah mempunyai arti berani (Susanto, 2007: 231). Kaitan warna yang terdapat pada quote pesan dakwah, gaun putih dan warna hena yang berwarna merah yang dipakai oleh pengantin perempuan bermakna keberanian yang dilandasi dengan tujuan yang suci. Pesan dakwah yang ingin disampaikan bahwa pernikahan adalah ikatan suci yang menjadikan keduanya mulia dan sah menjadi sepasang suami istri.

Tulisan quote dengan font freehand521B adalah kategori tulisan script. Jenis huruf ini menyerupai tulisan tangan sehingga memberikan kesan yang lebih alami. Alami bisa di maknai sebagai sifat mulia. Makna tulisan "Sungguh Menikah itu Mulia" pesan dakwah yang disampaikan melalui tulisan quote oleh pemilik akun yang di bawahnya terdapat tulisan @ nikahbarokah adalah tanda bahwa quote itu dibuat dan di posting oleh pemilik akun@nikahbarokah.

Makna mitos, gambar 3.3 quote menikah itu mulia membahas pesan dakwah tentang nikah. Pesan dakwah yang disampaikan, memberikan pesan bahwa pernikahan menjadikan seorang laki-laki dan perempuan terhormat karena ikatan pernikahannya yang menjadikan mereka sah menjadi pasangan suami istri dipandang mulia. Menikah itu sungguh mulia, mulia di hadapan Allah, dan para makhluknya.

Pesan dakwah yang disampaikan bahwa dalam tataran budaya penikahan adalah simbol kemuliaan yang terwujud dalam langkah untuk saling menutupi kekurangan pasangan. Melanjutkan keturunan dan kehidupan. Saling memuliakan antara suami istri. Karena tradisi dakwah islam mengajarka bahwa suami adalah pakaian bagi istrinya dan istri adalah pakaian bagi suami.

Pesan dakwah yang ada pada gambar 3.3 ini di perkuat dengan pernyataan menurut Bahtiar (2012: 12) ikatan pernikahan merupakan ikatan yang paling utama karena berkaitan dengan mengikat antara dua jiwa dengan ikatan cinta dan kasih. Sungguh pernikahan itu sangat mulia 
sehingga dengan pernikahan yang sah maka suami dan istri akan mendapatkan kedamaian, kecintaan, keamanan dan ikatan kekerabatan. Pesan dakwah yang disampaikan dalam quote ini memberikan pesan bahwa pernikahan dalam agama Islam menepati posisi yang sangat penting. Dibawah terdapat quote pesan dakwah tentang nikah membuka pintu rezeki yang diposting pada 11 Oktober 2017.

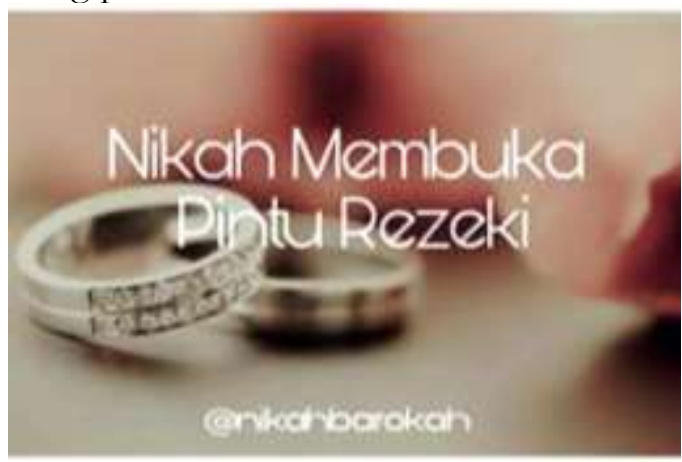

Gambar 3 Qute Nikah Membuka Pintu Rezeki

Makna Denotasi, pada gambar 3 pada quote di atas terdapat gambar kotak dengan background foto yang di blurkan dan sepasang cincin yang disimpan bersamaan yang satu cincin berbentuk polos dan yang satu cincin yang di atasnya terdapat permata sebagai latar depan (foreground). tulisan putih "Nikah Membuka pintu Rezeki" dengan font futura Bk BT dengan size font kurang lebih 24 yang dibawahnya terdapat tulisan @ nikahbarokah yang menandakan di buat oleh pemilik akun.

Makna Konotasi, Gambar 3 terdapat makna pesan dakwah tentang nikah. Dua cincin yang disimpan memberikan simbol pernikahan, dan foto cincin juga memberikan sebuah makna harta atau materi dalam quote "Nikah Membuka pintu Rezeki" dalam kamus Cincin kawin biasanya polos tidak memakai permata yang pada bagian dalamnya ada nama suami atau istri sebagai tanda sudah menikah (KBBI. 2008: 268). Simbol cin-cin menggambarkan kehidupan sehari-hari yang terus berputar seperti roda dan melambangkan kesetiaan karena bentuk cincin bulat tidak ada awal dan tidak ada akhir. Makna dari cincin dalam pernikahan, cincin memiliki bentuk yang bulat tidak ada batas (Zakaria. 2007: 68).

Makna tulisan quote "Nikah Membuka pintu Rezeki" dan @ nikahbarokah adalah pesan dakwah yang disampaikan oleh pemilik akun tentang nikah, bahwa menikah itu selain mulia menikah juga 
membukakan pintu rezeki, jangan takut untuk menikah, karena Allah maha kaya dan Allah telah menjajikan rezeki bagi yang ingin menikah dengan niat karean Allah dan ingin beribadah.

Makna Mitos, pada gambar 3 quote di atas menyampaikan pesan dakwah tentang pernikahan berhubungan dengan ketakutan seseorang dengan pernikahan yang mempermasalahkan materi atau rezeki yang disampaikan kepada orang orang yang takut menikah karena miskin maka al-Qur'an sudah terlebih dulu menjawabnya dalam Qs. An-Nur ayat 32 menurut (Lajnah. 2014: 90).

"Jika mereka miskin, Allah akan memberi kemampuan kepada mereka dengan karunia-Nya. Dan Allah Maha luas, Maha Mengetahui"

Alasan yang sering dikemukakan bujang menunda-nunda pernikahan hawatir terhadap kemiskinan yang akan menimpa kehidupan setelah berkeluarga. Alasan kemiskinan inilah yang dijawab oleh ayat 32 dalam surat An-Nur bahwa, jangan karena takut pada kemiskinan sehingga orang tidak mau menikah, sebab Allah yang akan memberi rezeki. Dan Allah Swt mampu melakukan hal itu, sebab Dia begitu Mahakuasa sehingga kekuasaan-Nya mencakup seluruh alam semesta, dan Dia begitu Mahatahu sehingga Dia mengetahui niat setiap orang, khususnya mengetahui niat orang yang memutuskan untuk menikah agar menyelamatkan kesuciannya. Karena itu Ja'far Shadiq mengatakan "Hidup akan menjadi sejahtera dengan menikah." Dan "orang yang tidak menikah karena takut miskin berarti berprasangka buruk terhadap Allah Swt.

Makna mitos Quote pesan di atas menyampaikan pesan bahwa jangan takut menikah karena alasan kemiskinan, dengan menikah akan membuka pintu rezeki berarti orang yang menikah itu mengumpulkan rezeki. Rezeki dari dua orang yaitu suami dan istri. Selain itu bertambah keluarga juga kerabat. Seorang suami lebih semangat mencari nafkah. Istri solehah ataupun suami yang soleh berakhlak baik, dan anak yang soleh/solehah adalah rezeki dalam sebuah kehidupan ruamh tangga. Mertua yang baik dan soleh juga bagian dari rezeki yang Allah berikan kepada kita.

\section{Pasca Nikah}

Konsep fisiologis terdapat pada sakinah dalam aspek pernikahan yaitu mempelajari berlangsungnya sistem kehidupan, untuk mengenali kebutuhan atau keinginan pasangan. Fisiologis adalah kebutuhan akan 
rasa aman (security needs), nyaman, dan disebut juga kebutuhan biologis (Adhim. 2002: 61).

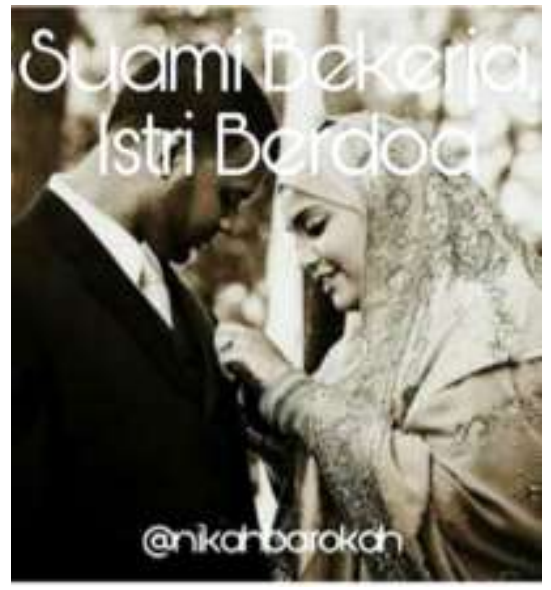

Gambar 4 Quote Suami bekerja, Istri Berdoa

Makna denotasi, pada quote gambar 4 di atas terdapat foto seorang perempuan yang memakai baju muslim sari berwarna coklat muda yang sedang merapihkan jas hitam yang dipakai seorang lelaki yang akan berangkat bekerja. Terdapat juga tulisan dengan font Tw Cen MT Condensed "Suami Bekerja, Istri Berdo'a" dan terdapat tulisan@nikahbarokah dibawahnya yang menendakan di posting oleh pemilik akun @ nikahbarokah

Makna konotasi, pada gambar 4 pada quote di atas "Suami Bekerja, Istri Berdo'a" memberikan pesan dakwah kepada pasangan suami istri dimana seorang istri mendo'akan yang terbaik untuk urusan keluarganya karena dibalik kesuksesan seorang lelaki ada seorang istri yang selalu mendo'akan suaminya untuk kelancaran dan keberhasilan usaha dan pekerjaannya. Foto di atas memberikan makna pesan bahwa istri yang baik selalu melayani suaminya dengan mempersiapkan kebutuhan seorang suaminya mulai dari bangun tidur, mau berangkat kerja, pulang kerja bahkan mau tidur.

Quote 4 memakai tulisan font Tw Cen MT Condensed termasuk pada karakter font black latter, dan warna hitam mepunyai makna formal, sedangkan warna coklat memiliki makana tenang kedamaian, tenang (Isroi. 2007: 48). Tulisan di atas mempunyai karakter yang has dan klasik. jika dikaitkan pada quote di atas maka sudah menjadi ciri khas dan sudah dari dulu bahwa kewajiban bagi seorang suami memberikan nafkah 
kepada istrinya. Dan makna warna hitam dari jas yang dipakai oleh lakilaki pada gambar di atas adalah pakain formal untuk bekerja, sedangkan sari berwarna coklat yang dipakai oleh seorang perempuan bermakna tenang dengan memberikan kesan hangat atau nyaman pada seorang suami dengan membantu merapihkan pakaiannya sebelum berangkat kerja.

Makna mitos pada gambar 4 menyampaikan pesan dakwah tentang nikah dalam aspek fisiologis yaitu melihat dari proses berlangsungnya kehidupan. Setiap kehidupan membutuhkan materi untuk membeli sandang, pangan, papan dan beribadah seperti sadaqah memerlukan materi. Sudah menjadi kebutuhan bahwa setiap manusia bekerja untuk mendapatkan materi. Kewajiban laki-laki untuk memberikan nafkah pada keluarganya. Menurut Syarief (2007: 66) seorang suami berkewajiban untuk menyelamatkan keluarganya dengan memberikan nafkah sandang, pangan, papan yang memadai. Dalam islam seorang suami dituntut untuk bekerja keras.

Pesan dakwah yang disampaikan dalam quote 3.5 berkaitan dalam budaya pekerjaan. Ajaran islam sangat menekankan pentingnya memberikan nafkah untuk memenuhi kebutuhan keluarga. Bekerja memberikan nafkah untuk diri sendiri dan keluarga dinilai sebagai ibadah dan amal shaleh. Memberikan nafkah pada seorang istri adalah kewajiban. Hak seorang istri adalah mendapatkan nafkah dari suami.

Di bawah terdapat postingan quote pesan dakwah tentang nikah yang berkaitan dengan sakinah pada tanggal 06 November 2016.

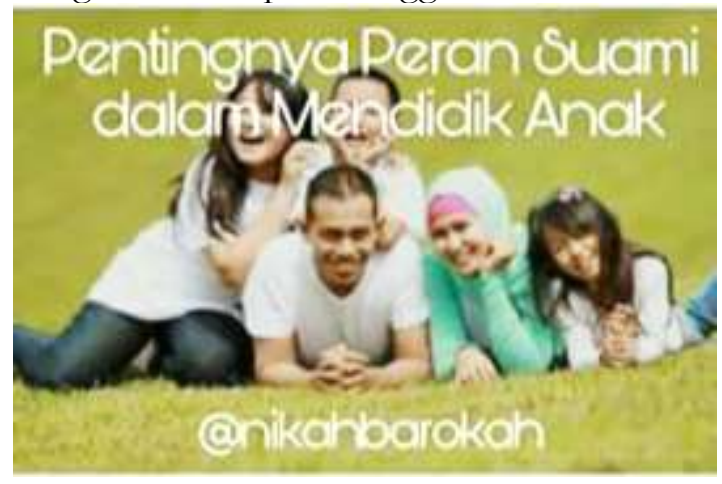

Gambar 5 Quote Sakinah

Makna denotasi, pada gambar 5 pada quote di atas terdapat foto seorang laki-laki dan perempuan dewasa dan tiga orang anak dua orang anak 
perempuan dan satu anak laki-laki Dengan background hijau di atas rumput dengan memakai baju putih dan ibunya memakai warna hijau muda.Pada foto digambar 5 terdapat quote tulisan putih dengan font futura $\mathrm{Bk} \mathrm{Bt}$ "Pentingnya Peran Seorang Suami dam Mendidik Anak" dan terdapat tulisan@nikahbarokah dibawahnya yang menandakan di posting oleh pemilik akun.

Makna konotasi, pada gambar 5 di atas terdapat sebuah foto dengan Backgraund hijau di atas rumput, warna hijau adalah warna yang sangat membumi warna hijau dapat mewakili sebuah pertumbuhan, permulaan baru dan kurang pengalaman, hijau juga dapat memeberikan efek penyeimbang dan pemberi harmonisasi yang dapat menstabilkan emosi. Baju yang di pakai warna putih adalah melambangkan bahwa anak-anak harus cerdas begitupun orang tua harus pintar-pintar dalam mendidik anaknya. Menurut (Soekarno. 2003: 26) hijau juga memberikan makna kreatif dan putih melambangkan kesucian, dan kecriaan.

Tulisan quote di atas "Pentingnya Peran Seorang Suami dam Mendidik Anak" peran seorang suami sekaligus seorang ayah bagi anakanaknya harus mampu mencontoh dan mengajarkan anak-anaknya untuk menegakan shalat, menjalankan amar ma'ruf nahi mungkar, mengjarkan untuk sabar dalam menghadapi ujian, tidak bersikap sombong, bersikap sederhana dan berbicara sopan.

Menurut Rehani prioritas (2003: 86) utama dalam memilih pendidikan untuk anak agar menjadi anak generasi yang berkualitas. pendidikan keluarga itu pada dasarnya ada dua yaitu pembentukan kepribadian dan kemampuan intelektual dan memberikan pendidikan iman, akhlak, jasmani, kesehatan intelektual, sosial dan seksual.

Makna mitos, pada gambar 5 adalah penyampaian pesan dakwah tentang fisiologis yang berkaitan dengan budaya pendidikan. Jika dikaitkan dengan budaya memang orang tua yang pertama mengajari anak anaknya. Akan tetapi sebelum mengajarkan pada anak awali dulu prosesnya mulai dari memilih pasangan yang baik karena jika orang tua yang baik maka akan mengahasilkan anak yang berkualitas. Jika di umpamakan seorang ayah adalah petani dan istri adalah ladang yang subur makan hasil panen padinya pun akan baik dan berkualitas. Seorang ibu dan ayah berperan sangat penting karena menjadi madrasah pertama dalam kehiduapan anaknya baik dalam pendekatan emosianal maupun spiritual. Tahapan dalam mendidik anak harus dimulai sedini mungkin, mulai dari kehamilan sebelum bayi lahir, setelah bayi lahir kecenderungan anak terhadap 
keyakinan agama, dan setelah anak-anak menginjak tahap remaja.

Anak sesungguhnya amanah Allah yang dititipkan kepada kita sebagai orang tua dan setiap amanah akan di mintai pertanggung jawaban nya diakhirat. Menurut Mustaqim (2005: 19) keturunan merupakan hal penting dalam kelanjutan misi kekhalifahan manusia dibumi Maka anak yang sholeh dan berkuaitas merupakan generasi penerus untuk kemajuan dan kemakmuran bumi dan anak-anak harusnya mendapatkan pendidikan yang baik agar menjadi anak yang bermanfaaat untuk keluarga, umat bangsa dan negara. Pesan dakwah pada gambar di atas bahwa pendidikan dalam keluarga itu sangat penting.

Konsep Psikologis diambil dari mawadah dalam pernikahan adalah mempelajari tentang ilmu mengenai prilaku, sikap, fungsi dan proses mental dalam sebuah keluarga (Petranto. 2005: 11).

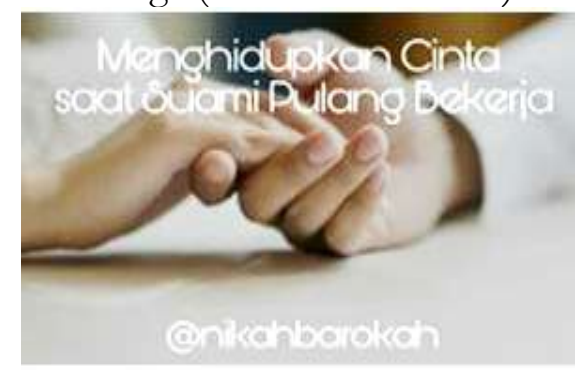

Gambar 6 Quote menghidupkan Cinta

Makna denotasi, pada Gambar 6 terdapat gambar kotak dengan foto pegangan tangan dan tulisan. Tangan kanan seorang perempuan yang lentik dipegang oleh tangan kanan laki-laki di atas meja dengan tulisan warna putih menggunakan font futura $\mathrm{Bk}$ Bt dengan karakter san serif. Tulisan quote di atas "Menghidupkan Cinta saat Suami Pulang Bekerja" dan dibawahnya tulisan@ @ikahbarokah yang diposting oleh pemilik akun.

Makna konotasi tulisan quote Gambar 6 di atas "Menghidupkan Cinta Saat Suami Pulang Bekerja" memberikan pesan dakwah pada perempuan atau seorang istri harus bisa membuat suami tenang dan nyaman saat suami pulang bekerja, menghidupkan cinta saat suami pulang bekerja salah satunya dengan menyambut suami dengan memberikan pelayanan dan hiasan terbaik.

Makna dari foto quote di atas tangan yang sedang dipegang, terdapat konotasi bahwa tangan istri menggenggam tangan suami. Hal ini dalam 
kaitan pesan dakwah dalam quote di atas bahwa istri menyambut hangat kedatangan suami dengan memberikan sentuhan cinta. Salah satu hadis mengenai signified quote di atas dari ar-Rafi' dari Abu Sa'id al-Khudri

"Jika suami memandang istrinya dan si istri memandang suaminya, maka Allah akan memandang keduanya dengan pandangan rahmat. Jika suami memegang telapak tangan istrinya, maka berguguranlah dosa-dosa keduanya dari sela-sela jari mereka." (al-Farisi, 2008: 54).

Tulisan putih dengan font futura Bk Bt mengandung makna bahwa warna putih juga bisa diartikan lemah lembut, dengan kategori font blok dengan dengan karakter yang tebal suka digunakan untuk judul tagline atau hadline ini berkaitan dengan kedalaman cinta dari seorang istri terhadap suaminya dengan pengaplikasian dalam pelayanan terbaik secara lemah lembut terhadap suami dan nada seorang istri tidak boleh lebih tinggi dari nada suami itulah sebabnya serang istri harus lemah lembut.

Makna mitos g ambar 6 quote pesan dakwah tentang nikah di atas pesan untuk seorang istri yang sudah menikah. Pesan dakwah yang disampaikan berkaitan dengan budaya kehidupan suami istri. Ketika suami datang, pulang dari tempat bekerjanya seorang istri harus menyambut kedatangannya dengan senyuman dan raut wajah yang ceria, memberikan hiburan, menyiapkan makanan dengan keadaan rumah yang rapih. Perhatian yang dilakukan seperti itu adalah bentuk cinta seorang istri dengan memberikan kenyamanan saat suami pulang bekerja. Pesan dakwah ini juga menyampaikan pesan agar hubungan suami istri dalam rumah tangga terjaga keharmonisannya dengan semakin bertambah mawadah di antara keduanya.

Di bawah terdapat quote pesan dakwah tentang istri yang romantis yang diposting pada 10 November 2016.

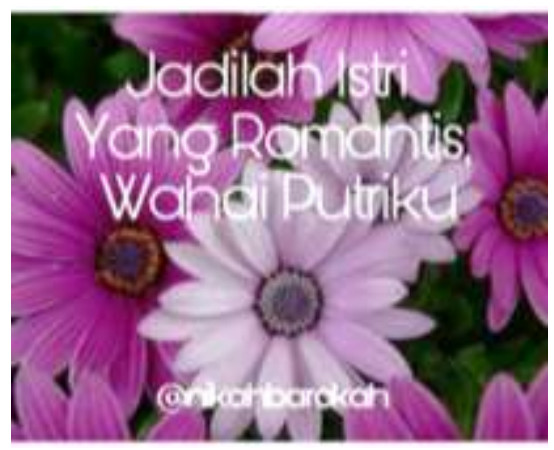

Gambar 7 Quote Istri Romantis 
Makna denotasi quote gambar 7 terdapat gambar kotak dengan dua objek. Objek yang pertama background foto bunga aster yang berwarna ungu muda dan ungu sedikit tua dan terlihat sedikit daun yang berwarna hijau karena tertutup dengan besarnya bunga. Objek yang kedua terdapat sebuah tulisan dengan kata-kata "Jadilah Istri Yang Romantis Wahai Putriku" yang berwarna putih dan dibawahnya tertulis@ @ nikahbarokah yang berarti di posting oleh pemilik akun@nikahbarokah.

Makna konotasi gambar 3.8 quote pesan dakwah di atas adalah bunga daysi atau bunga aster dan berdaun hijau adalah bunga yang indah, cantik, dan eksotis. Dalam salah satu artikel makna dari bunga aster adalah merupakan lambang cinta, kesetiaan, dan kesabaran (wartikel. 2017). Bunga aster memiliki banyak warna, salah satunya adalah foto bunga aster pada gambar 7 di atas yang berwarna ungu muda dan berwarna ungu tua. Warna ungu muda diartikan dengan lebih mengekspresikan romantisme dan percintaan dan ungu tua memberikan arti anggun (Yoga. 2005: 58).

Romantis dalam KBBI (2008: 1180) bersifat seperti dalam cerita roman (percintaan), bersifat mesra, dan mengasyikan. Pesan dakwah jadilah istri yang romantis pada quote di atas bahwa perlakuan romantis dalam hubungan suami istri bagaikan bumbu yang memberikan rasa pada makan. Tulisan quote yang paling bawah@nikahbarokah menandakan bahwa tulisan tersebut di buat dan di posting oleh pemilik akun

Makna mitos quote gambar 7 berkaitan dengan pesan dakwah tentang mawadah yang membahas kebiasaan seorang istri yang romantis para perempuan atau seorang istri yang sudah menikah agar menjadi seorang istri yang bersikap romantis. Sikap romantisnya seorang istri terhadap suaminya adalah bentuk dari kecintaan seorang istri terhadap suaminya. Seorang istri yang romantis mampu menjadi pasangan suaminya secara biologis dan psikologis yang membuat pasangan atau suami mendapatkan ketenangan,dan kenyamanan secara lahir dan batin. kenyamanan inilah yang di sebut dengan mawadah yang terdapat dalam pernikahan. Pesan dakwah yang berkaitan dengan quote ini terdapat dalam al qur'an surat Ar-Rum ayat 21.

"Dan di antara ayat-ayat-Nya ialah Dia menciptakan untukmu istriistri dari sejenismu sendiri, supaya kamu merasa nyaman kepadanya, dan dijadikan-Nya di antaramu mawadah dan rahmah. Sesungguhnya pada yang demikian itu benar-benar terdapat tandatanda bagi kaum yang berpikir". 
Penikahan dalam islam bertujuan untuk meraih ketentraman dalam ikatan cinta yang halal sehingga suami istri merasakan ketenangan, kebahagiaan dan kedamaian. Manusia mempunyai perasaan terhadap lawan jenis yang timbul dari daya tarik pada masing-masing yang menjadikan keduanya terjalin hubungan yang wajar dan berusaha agar perasaan dan kecenderungan keduanya dapat tercapai. Puncak dari semua itu ialah pernikahan. Dalam keadaan seperti itu maka bagi laki-laki hanya istrinya perempuan yang paling baik dan menarik hatinya (Depag RI. 2010: 481).

Konsep sosiologis dalam rahmah terdapat dalam quote yang di posting oleh akun@nikahbarokah pada 17 Oktober 2016.

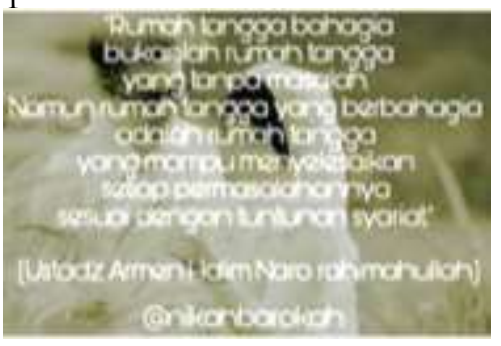

Gambar 8 Quote Rahmah

Makna denotasi quote $8 \mathrm{di}$ atas terdapat foto laki-laki dan perempuan dengan background dialam terbuka dirumpunan alang-alang seorang perempuan dan laki-laki yang memakai baju warna putih yang mana seorang laki laki sedang memandang perempuan dan seorang perempuan yang sedang memegang alang-alang.

Terdapat tulisan quote di atas, dibawahnya terdapat nama yang di beri tanda kurung yaitu Ustadz Armen Halim Naro Rahimahullah dan @nkahbarokah. Nama yang di beri tanda kurung adalah quote dari Ustadz Armen yang dikutip, di tulis dan diposting oleh pemilik akun @ nikahbarokah.

Makna konotasi gambar 8 terdapat pesan dakwah tentang sakinah quote ini adalah pesan dakwah yang disampaikan kepada orang yang akan dan sedang menjalani kehidupan rumahtangga, jika kita berpikir bahwa pernikahan yang kita jalani akan berjalan mulus dan selalu diliputi dengan kebahagian tidak ada perselisihan, kekesalan dan kemarahan, itu hanya angan angan. Sudah menjadi hukum alam bahwa lika liku kehidupan rumah tangga pasti ada karna jalan pun tidak selalu lurus. Sudah menjadi sunatullah bahwa dalam pernikahan pasti akan ada romantika kehidupan. 
Tulisan nama Ustadz Armen Halim Naro Rahimahullah dalam kurung dan@nikahbarokah yang terdapat pada gambar quote 3.9 adalah pesan dakwah yang disampaikan oleh Ustadz Armen Halim Naro Rahimahullah yang dikutip oleh pemilik akun@nikahbarokah dan ditulis dalam quote yang diposting dalam akun@nkahbarokah.

Makna konotasi yang berkaitan dengan background di atas, tumbuhan alang-alang itu sendiri adalah tumbuhan yang mempunyai akar yang sangat kuat yang memiliki zat kimia bernama allelophaty (Nuralammn. 2012). Jika dikaitkan dengan quote, foto di atas memberikan pesan bahwa hubungan sebuah kehidupan rumah tangga harus kuat seperti akar tumbuhan yang dimiliki alang-alang yang bisa menghambat tumbuhan yang disekitarnya sama halnya seperti masalah yang muncul dalam kehidupan rumah tangga harus bisa meminimalisir masalah yang terus bermunculan, agar tidak berujung perceraian

Makna mitos yang terdapat pada gambar 3.9 di atas terdapat pesan dakwah yang berkaitan dengan sosiologis dalam pernikahan tentang sakinah. budaya pertengkaran dalam setiap kehidupan rumah tangga tidak pernah luput dalam setiap perjalanan hidup rumah tangga. Tidak ada yang tidak mempunyai masalah, semua kehidupan rumah tangga akan dihadapkan dengan berbagai masalah maka dari itu kita harus sadar betul bahwa pasangan kita bukan seseorang yang sempurna pasangan kita juga manusia biasa yang pasti mempunyai kekurangan. Dari kekurangan itulah kita harus bisa paham dalam menyikapi setiap masalah yang ditimbulkan oleh pasangan kita atau masalah yang ditimbulkan dalam keluarga atau anak-anak kita. Dengan mengambil jalan keluar dengan ketentuan syari'at dan hukum-hukum yang sudah ditentukan.

Menurut Junaidi dan Riana (2008: 5) bahwa rumah tangga yang harmonis itu bukanlah rumah tangga tanpa perselisihan, melainkan rumah tangga yang dapat menjadikan perselisihan sebagai bunga-bunga yang memberi warna pada pernikahan Dengan minciptakan saling kerja sama antara pasangan suami dan istri akan sama-sama kerja dalam memecahkan masalah.

\section{PENUTUP}

Pesan dakwah tentang nikah dalam instagram akun@nikahbarokah. Berdasarkan hasil penelitian pesan dakwah tentang nikah dalam akun instagram@nikahbarokah terdapat 3 pesan, yaitu pesan dakwah tentang nikah, mulai dari pesan dakwah tentang ta'aruf, nikah, dan pasca nikah 
dalam aspek fisiologis (sakinah), psikologis (mawadah), dan sosiologis (rahmah) yang diteliti menggunakan teori semiotika berdasarkan makna denotasi, konotasi dan makna mitos yaitu sebagai berikut:

Pesan dakwah tentang nikah ditemukan dalam postingan yang berkaitan dengan ta'aruf, pesan dakwah tentang ta'aruf terdapat dalam quote pertama yaitu gambar cermin. Makna denotasinya cermin dan quote, makna konotasinya cermin sebagai gambaran pasangan dalam diri kita dan makna mitosnya di masyarakat cermin adalah alat untuk berkaca. Mengenai pesan dakwah tentang ta'aruf seperti memantaskan diri dengan bercermin pada diri untuk memperbaiki pribadi dari pada memilih pacaran.

Pesan dakwah tentang nikah terdapat dua quote, pesan dakwah bahwa menikah itu mulia dan menikah membuka pintu rezeki. Makna denotasinya terdapat gambar gaun pengantin putih dan cincin. Makan konotasinya bahwa gaun berwarna putih adalah kehormatan dan kemuliaan sebagaimana pernikahan itu mulia, dan cincin adalah simbol dari rezeki dan makna mitosnya bahwa di masyarakat pernikahan sebagai hubungan yang sah agar laki-laki dan perempuan tidak dipandang hina dan dengan menikah keluargapun bertambah.

Pesan dakwah tentang pasca nikah, terdapat 5 quote yang berkaitan dengan sakinah (fisiologis), mawadah (psikologis), dan rahmah (sosiologis) terdapat makna denotasi, yaitu unsur gambar dan quote yang berkaitan dengan sakinah, mawadah dan rahmah. Makna konotasinya terdapat makna tentang pendidikan, nafkah, keharmonisan, ketentraman dan kasih sayang. Makna mitosnya terdapat dalam kehidupan setelah menikah bahwa dalam keluarga membutuhkan nafkah dan anak-anak mendapatkan hak pendidikan serta suami istri menjalani kehidupan rumah tangga harus dengan saling memahami, pengertian dengan komunikasi yang sering agar tidak terlalu banyak salah paham dan dapat menyelesaikan masalah dengan kepala dingin.

Hasil dari penelitian ini dapat disimpulkan bahwa pesan dakwah tentang nikah yang diposting pengelola akun@ @ikahbarokah selama bulan Oktober sampai Desember 2016 terdapat 8 quote pesan dakwah. Diklasifikasikan berdasarkan tahap pernikahan yaitu ta'aruf, nikah dan pasca nikah dalam aspek fisiologis (sakinah), psikologis (mawadah), dan sosiologis (rahmab). Secara denotatif, konotatif dan mitos.

Berdasarkan hasil penelitian pesan dakwah tentang nikah di media sosial instagram, peneliti memberikan saran: Kepada pengelola akun 
Nurasiah Ismail, Zainal Abidin, dan Uwes Fatoni

@ nikahbarokah dalam menyajikan pesan dakwah dalam quote-quote yang lebih menarik lagi dan memperbaharui pengemasan pesan-pesan dakwah yang akan dipostingkan, agar para followers@nikahbarokah yang masih pacaran, segera terketuk pintu hatinya untuk segera memperbaiki diri, dan menikah, followers yang sudah menikah agar senantiasa belajar terus untuk menjadi istri solehah. Selain itu perbanyak juga pesan dakwah untuk para lelaki agar menjadi suami soleh yang sealau menjaga keharmonisan serta tanggung jawab sebagai seorang kepala rumah tangga. Kepada para akademisi yang akan melakukan penelitian yang sama, berkaitan dengan pesan dakwah di media sosial instagram agar mengkaji dari sudut pandang lain.

\section{DAFTAR PUSTAKA}

Adhim, M. F. (2002. Indahnya Pernikahan Dini. Jakarta: Gema Insani

Afandi, B. (1984). Beberapa Percikan Jalan Dakwah. Surabaya: Fakultas Dakwah Surabaya.

Al -Farisi, M. Z. (2008). When I Love You. Jakarta: Menuju Sukses Hubungan Suami Istri: Gema Insani

Amin, S. M. (2009). Ilmu Dakwah. Jakarta: Amzah

Aziz, A. (1997. Ishlah al-Wakhudu al-Diniy, Mesir: Attiqarah a-Kubra

Bahtiar, D. S. (2012). Ladang Pahala Cinta: Berumah Tangga Menuai Berkah. Jakarta: Amzah

Bambang. (2012. Instagram Handbook. Jakarta: Media Kita

Chudlori, M. Y. (2012). Baiti Jannati: Sudabkah Keluarga Anda Sakinah?. Bandung: Marja

Dahlan, R M. (2015). Fikih Munakahat. Yogyakarta: Deepublish

Daryanto. (2014). Teori Komunikasi. Gunung Samudra: Malang

Departemen Agama RI. (2010. Al-Qur'an dan Tafsimya (Edisi yang Disempurnakan). Jakarta: Lentra Abadi

Departemen Pendidikan Nasional. (2008). Kamus Besar Bahasa Indonesia. Jakarta: Gramedia Pustaka Utama

Faqih. A. K. (2006). Tafsir Nurul Qur,an. Jakarta: Al-Huda

Hikmat. (2011). Pesan-Pesan Dakwah Dalam Bahasa Tutur. Ilmu Dakwah: Academic Journal for Homiletic Studies, 5(1), 259.

Instagram. (2017). Nikahbarokah. Diakses 10 Oktober 2017, dari .http://www.instagram.com/nikahbarokah.

Isroi. (2005). Trik Desain Presentasi Dengan Microsoft Office Power Point 2003. Jakarta: Media Komputindo 
Junaidi dan Riana, U. D. (2008). Menjadi Istri Yang Layak Dicintai. Madanisa: Bandung

Kamil, R. (2014). \#TETOT “Aku, Kamu, Media Sosial”. Bandung: Sugma Creative Media Crop.

Lajnah Pentahsihan Mushaf Al-Qur'an. (2004). Tafsir Amorissan.l-Qur'an Tematik. Jakarta: Kamil Pustaka.

Mustaqim. A. (2005). Menjadi .Orang Tua Bijak. Mizan: Bandung

Nuralammn. (2012). Filosofi Alang-alang. Diakses 11 November 2017, dari http://alammn.wordpress.com/filosfi-alang-alang.

Rehani, Z. D. (2003). Berawal dari Keluarga revolusi belajar cara Al-Quran. Jakarta: Hikmah

Sahrani, T. dan Sohari. (2013. Fikih Munakahat. Jakarta: Rajawali Pers

Sobur, A. (2004. Semiotika Komunikasi, Bandung: Remaja Rosdakarya

Soekarno \& Basuki, L. (2003). Desain Ilustrasi Busana. Jakarta: Kawan Pustaka

Sudarsono. (1991). Hukum Kekeluargaan Nasional. Jakarta: Rineka Cipta.

Susanto, B. (2007). Sisi Senyap Politik. Yogyakarta: Kanisius.

Syarief, S. (2007). Menggapai Keluarga Berkualitas Dan Sakinah. Jakarta: Mitra Abadi Pers.

Syuaisyi', S. H. A. (2005. Kado Pernikahan. Jakarta: Pustaka Al-Kautsar

Tasmara, T. (1997). Komunikasi Dakwah . Cet. II; Jakarta: Gaya Media Pratama.

Wartikel. (2012). Arti Bunga Aster dan Fakta Menarik, diakses 24 November 2017, dari http://wartikel.com/arti-bunga-aster.

Widjaja. C. (2006). Adobe InDesign, Cetak - Digital. Jakarta: Widjaja

Yoga. (2005). CorelDRAW untuk Bisnis. Jakarta: Media Komputindo

Zahrah, A. (1994). Dakwah Islamiah. Bandung Rosdakarya

Zakaria, L. (2007). Let's Get Married. Jakarta: Penebar Plus. 